\title{
Fortid og fremtid
}

- nogle tanker i anledning af et jubilæum

\author{
af Hans H.Worsøe
}

Da jeg på årsmødet i Gram i maj 1986 blev valgt til formand for Historisk Samfund for Sønderjylland efter Poul Andersen, overtog jeg ledelsen af en velkonsolideret forening med et stort apparat bag sig. Det var en forening med en lang række traditioner og en lang række forpligtelser. Medlemmerne forventede hvert år en stor og veludstyret årbog, de forventede at der blev arrangeret en egnsvandring, og ikke mindst forventede de hele tiden nye og velskrevne bøger såvel $\mathrm{i}$ den lille serie af Sønderjyske Levnedsløb som i skriftrækken med de tungere, men videnskabeligt velunderbyggede bøger. Dertil kom Sønderjysk Månedsskrift, som på sin vis kørte sit eget løb. Endelig var der - uden at det må misforståes - $\mathrm{i}$ anden række aktiviteterne $\mathrm{i}$ amtskredsene. For at få alt dette til at fungere var det efterhånden blevet nødvendigt med fast kontorhold, og nu stod også dataalderen for døren med krav om investeringer i »Systemer«, men hvad: regnskabet 1985 viste jo en beholdning på over $600.000 \mathrm{kr}$.

Hvad de færreste tænkte på var, at en væsentlig del af beholdningen var øremærket til planlagte publikationer, at det faste tilskud fra amtet ikke længere dækkede de stadigt voksende administrationsudgifter, og at medlemstallet, trods en meget ihærdig indsats på dette punkt, ikke længere voksede. Der var altså skyer $\mathrm{i}$ horisonten, men lige så alvorligt var det nok, at udviklingen sude $\mathrm{i}$ amtskredsene« forlængst var løbet fra en central styring. Man ville, og man kunne selv $\mathrm{i}$ de spontant opståede lokalhistoriske arkiver og sognehistoriske arbejdsgrupper, således som Poul Andersen så rigtigt nævner det i sin artikel.

Problemerne var ikke blevet fejet ind under gulvtæppet i Historisk Samfunds styrelse, men derimod gentagne gange drøftet på møderne. Meningerne var delte, således som de naturligt vil være det $i$ en bestyrelse. De spændte fra, for at nævne nogle af yderpunkterne, at nedlægge amtskredsene og omdanne Historisk Samfund til et udgiverselskab og til at reorganisere Historisk Samfund som en paraplyorganisation for de lokale historiske foreninger med et repræsentantskab og overvejende indirekte valg til styrelsen. Med hensyn til 
økonomien levede man endnu stort set videre i tiltro til, at hvis de offentlige tilskud svandt ind, ville der altid være fonds og legater at støtte sig til.

Dette gjaldt både den almindelige drift, skrifterne og ikke mindst Sønderjysk Månedsskrift, som ingen forestillede sig kunne løbe rundt økonomisk. Efter at Inger Bjørn Svensson oven på sin imponerende indsats siden 1963 som hoved-, senere eneredaktør, i sommeren 1986 havde trukket sig tilbage, var en ny redaktion tiltrådt, bestående af 3 medlemmer i erkendelse af, at redaktionsarbejdet var mere end en person med normal arbejdskraft kunne klare. Årgangen ud og også næste årgang beholdt man det vanlige format og den populære kulørte forside med de to løver, men bag kulisserne arbejdedes der med fornyelsen, som blev giort til genstand for en gennemgribende drøftelse på styrelsens efterårsmøde i 1986, hvor den nye redaktion fremlagde sine planer. Da det viste sig, at et ændret format kunne spare mange penge, vovede man fra årgang 1988 at gå ned til det populære "Skalk-format « og valgte samtidig en sats, hvor man kunne udnytte det nyanskaffede EDB-anlæg. Aftalen med Museumsrådet om museumsårbogen blev ændret til begge parters tilfredshed, og med den traditionsrige Grænselandskronik, som var arvet fra Grænsevagten, gik man helt nye veje. Endog skribenter fra mindretallet kom her på tale. Resultatet blev en gennemgribende forandring, uden at det gik ud over kvaliteten. Indholdet nød tværtimod godt af en friere opsætning og øget anvendelse af billeder. Det nye Månedsskrift slog an, og det lykkedes at sætte abonnenttallet $\mathrm{i}$ vejret fra ca. 1700 til ca. 2200 , hvilket så absolut har en gavnlig indflydelse på økonomien.

Når ovenstående er refereret så indgående er det, fordi det er et godt eksempel på, at der selv på områder, hvor man synes det går optimalt, kan gøres en fornyet indsats, som viser sig at bære god frugt. Ud fra denne indstilling til opgaverne blev der på samme styrelsesmøde i 1986 efter kassererens oplæg nedsat et PR-udvalg, der fremover skulle koordinere markedsføringen af foreningen og dens produkter. Udvalget har siden da forestået en modernisering af brochuremateriale og i det hele taget sørget for den udadvendte side af Historisk Samfunds virksomhed bl.a. i forbindelse med præsentationen af nye bøger. Udvalget har dermed bidraget væsentligt til at give foreningen et bedre og mere markant image.

På samme begivenhedsrige bestyrelsesmøde, som fandt sted i november 1986 som et todagesmøde i Frøslevlejren, besluttedes det at fordoble det årlige dispositionsbeløb, som amtskredsene kan råde over til deres lokale arbejde. På næstformandens initiativ blev der desuden indført årlige fællesmøder med samtlige amtskredsbestyrelsesmedlemmer, således at disse kunne udveksle ideer $\mathrm{g}$ fra bestyrelsens side blive holdt underrettet om nye tiltag. Amtskredsenes bestyrelsesmedlemmer kommer på denne måde til at fungere som en slags 
tillidsmænd for Historisk Samfund i de lokale kredse og udfylder dermed det tomrum, der opstod, da den tidligere tillidsmandsordning efterhånden gik $\mathrm{i}$ opløsning. Som en styrkelse af det lokale arbejde skal det også ses, at Historisk Søndag på initiativ af Aabenraa amtskreds forsøgsvis er genindført, og at de 7 foredragsholdere, som i vinteren 1988/89 præsenterede syv tværsnit af Sønderjyllands historie ved en foredragsrække på Landsarkivet i Aabenraa, alle har stillet sig til rådighed, samlet eller enkeltvis, for foredragsarrangementer andre steder $\mathrm{i}$ landsdelen.

Med hensyn til Sønderjyske Årbøger har kræfterne været koncentreret om denne jubilæumsbog og ikke mindst om 100-års registeret, hvor fhv. skoleinspektør Børge L. Barløse skal takkes for sin helt enestående arbejdsindsats. Den opmærksomme læser vil dog også have opdaget, at årbøgerne fra og med 1987 har indeholdt et afsnit med beretninger fra de lokalhistoriske organisationer og arkiver i Sønderjylland, et afsnit der i samarbejde med LASS udsendes som særtryk bl.a. til alle kulturudvalgsmedlemmer $\mathrm{i}$ kommunerne og til amtsrådets medlemmer. Historisk Samfunds egen beretning optræder her sammen med de øvrige store og små foreningers. Der er således tale om et samarbejde, hvor Historisk Samfund nok stiller sit apparat til disposition, men ellers går ind på lige fod med de øvrige foreninger og arkiver. Det er efter min opfattelse samarbejde af denne karakter, der i langt højere grad er brug for, end at Historisk Samfund skulle være paraplyorganisation eller førerhund. Når 100-års jubilæet er passeret, er Sønderjyske Årbøgers fremtidige forhold sat på dagsordenen ved det næste styrelsesmøde. Der skal nok komme nye ideer frem. Om de kan realiseres, vil de næste 5-6 år vise.

Også Historisk Samfunds skriftrække passerer $i$ år et rundt årstal, nemlig de 50 år. Når det ikke udadtil markeres så tydeligt, hænger det nøje sammen med et helt væsentligt træk i skriftrækkens struktur. Den er nemlig i meget ringe grad en række af planlagte skrifter, men i høj grad styret af udefra kommende forslag $i$ form af manuskripter indsendt til os med forslag om udgivelse. Der er dog undtagelser, først og fremmest bøgerne om Aabenraa kommunes, incl. Løjt og Ensted sognes historie og en del af bøgerne uden for selve skriftrækken, nemlig i den lille serie af sønderjyske levnedsløb og sidst men ikke mindst Peter Kr. Iversens genistreg: Billedbøgerne. I det for øjeblikket siddende skriftudvalg er der en ganske klar opfattelse af, at det kunne være ønskeligt selv fremover i noget højere grad at styre aktiviteterne inden for alle rækker af publikationer, en opfattelse, som forhåbentlig i de kommende år vil give sig udslag i spændende initiativer, som det imidlertid på nuværende tidspunkt ville være forkert at løfte sløret for. Vi vil således også her kunne forvente, at Historisk Samfunds profil vil ændre sig som udslag af en bevidst indsats fra styrelsens side. 


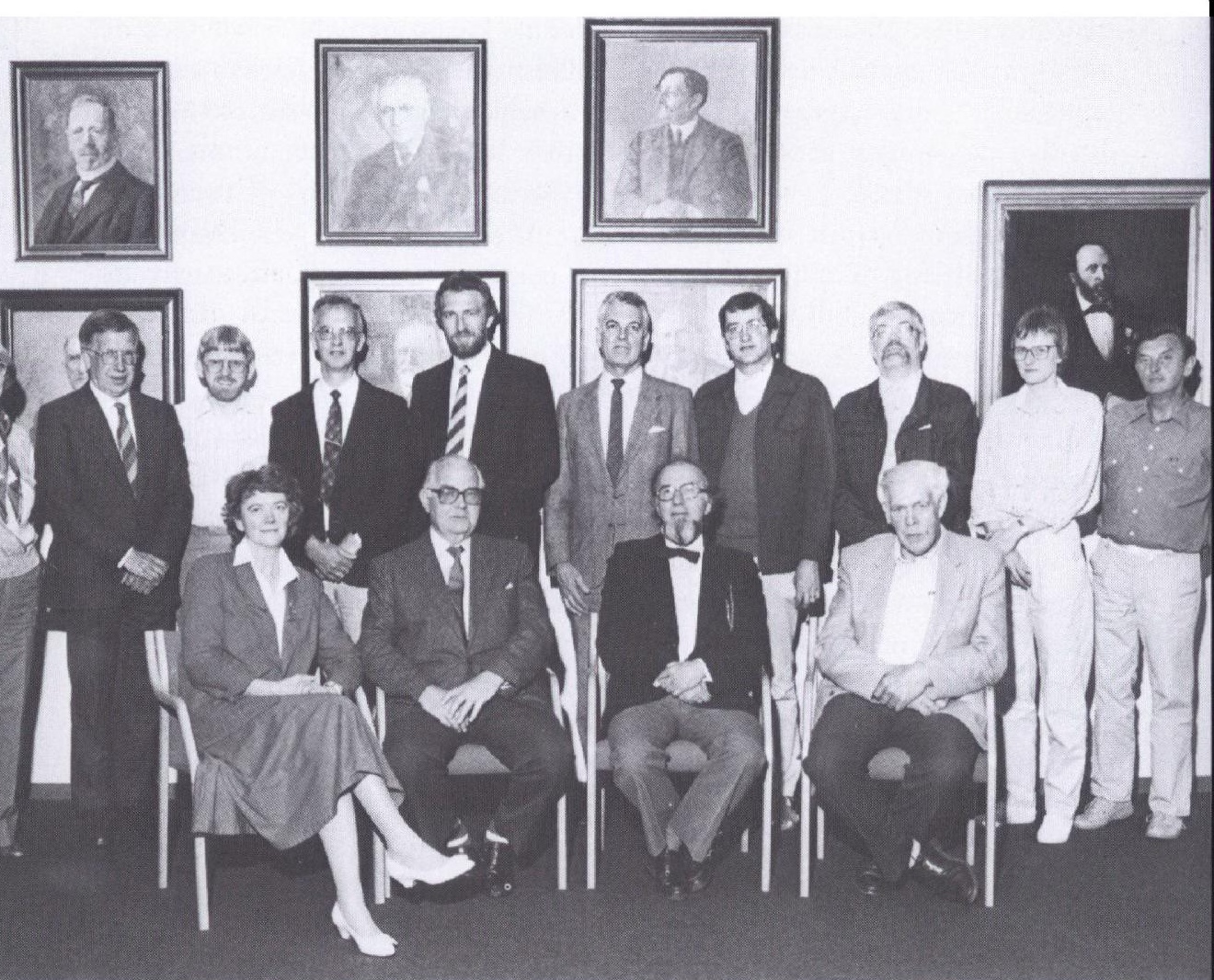

Historisk Samfunds styrelse fotograferet i Billedsalen på Folkehjem den 20.maj 1989. Bageste rakke fra venstre: foreningens kontorleder Vera Molberg Hansen og derefter Hans H.Bang, Henning Mathiesen, Rasmus Callesen, Henrik Becker-Christensen, Ole Perch-Nielsen, Henrik Fangel, Niels H.Kragh Nielsen, Marie Moller og Peter Madsen. Forreste rakke fra venstre: Inge Adriansen, Knud Fano, Hans H.Worsee og Soren Rasmussen. Steen W.Andersen, Lars N.Henningsen, Hans Schultz Hansen og Johann Runge var fravarende. Foto Th. Lawaetz.

Da vi år fejrer en række jubilæer, må det være tilladt her at komme med et par almindelige bemærkninger om Historisk Samfund for Sønderjyllands deltagelse i jubilæumsarrangementer. Jeg tænker ikke på de specielle sønderjyske jubilæer, da vi som landsdelens historiske bevidsthed naturligvis bør være med til at markere disse, men jeg tænker på de jubilæer, hvor man har diskuteret, om de skulle fejres i Sønderjylland. Der har været en række af disse i de seneste år, f.eks. Christian 5s Danske Lov, Stavnsbåndsjubilæet og nu i 1989: 100 års jubilæet for den danske arkivlov af 30.marts 1889. Sidstnævnte er måske ikke så markant, som de andre, hvoraf jo især Stavnsbåndsjubilæet markerede sig i medierne. Men fælles for dem alle er, at man har hørt 
røster, der har argumenteret mod markeringen af disse jubilæer i Sønderjylland ud fra den (rigtige) betragtning, at de pågældende love og forordninger jo ikke gjaldt i Sønderjylland. Om de pågældende i stedet påtænkte at fejre forlængst ophævede slesvigske særlove, for ikke at tale om forordninger og begivenheder foranlediget af myndighederne i perioden 1864-1920, ved jeg ikke, men det er vel næppe troligt. Meningen med at drage disse forhold frem er imidlertid, at vi som historisk organisation må gøre os det klart, at selv om vi har vor egen fortid, så er vi en del af den danske nutid med den deraf følgende forpligtelse til som noget naturligt også at markere de rent »kongerigske« jubilæer.

Historisk Samfund for Sønderjylland vil gerne fremover fortsat gøre en indsats for at styrke den historiske bevidsthed $\mathrm{i}$ landsdelen. Vi vil gøre det sammen med de øvrige historiske foreninger og organisationer i hele Sønderjylland, og vi vil gerne udbygge samarbejdet med dem. Et skridt i denne retning er arrangementet af såkaldte temadage, som blev introduceret af den landsdækkende Sammenslutning af Lokalhistoriske Foreninger (SLF) ved et møde på Folkehjem i 1986, og som senere er blevet fulgt op af to temadage arrangeret af Historisk Samfund, Sammenslutningen af lokalhistoriske arkiver og samlinger i Sønderjylland (LASS) samt Historisk Samfund for Als og Sundeved i fællesskab. Temadagene er forbeholdt medlemmer af de enkelte foreningers styrelser og er beregnet på at give viden og inspiration til fornyelse i arbejdet. Som eksempel kan nævnes, at emnet for temadagen i november 1988 var »Hvordan bevarer vi vore gamle landsbyer og kirkegårde?« Historisk Samfund vil også gerne i de kommende år medvirke ved afholdelse af temadage, men samtidig vil vi gerne markere vor egen profil, således at det bliver naturligt at være medlem af Historisk Samfund for Sønderjylland for alle, der interesserer sig for historie og arbejder med Sønderjyllands historie eller blot en enkelt lokalitets historie og dens mennesker. Det er muligt, at vi derfor skal differentiere vore medlemstilbud. Vi har allerede indført et fælleskontingent for medlemskab og abonnement på Sønderjysk Månedsskrift, således at der er en fordel ved at holde begge samtidig. På det sidste møde med amtskredsbestyrelserne blev den tanke fremsat, at man som medlem måske i stedet for burde kunne vælge mellem Sønderjyske Årbøger og Sønderjysk Månedsskrift. Tanken er interessant og bør givetvis drøftes, selv om den nok i første omgang vil virke chokerende for nogle. Hvis den imidlertid indebærer, at vi kan få et bredere udsnit af befolkningen som medlemmer, kan den måske vise sig at være positiv nytænkning. Et må imidlertid slåes fast her i Sønderjyske Årbøgers 100-års jubilæumsår: Udgivelsen af Sønderjyske Årbøger er og vil fortsat være en af Historisk Samfund for Sønderjyllands allervigtigste, for ikke at sige den vigtigste af vore opgaver. Derom må der ikke såes tvivl. 
Når man er medlem af Historisk Samfunds styrelse, er man også medlem af et eller flere udvalg. Det er her det egentlige arbejde foregår, og det er medlemmerne af disse udvalg, der former Historisk Samfunds fremtid. Nye planer bliver altid gennemdrøftet $i$ hele styrelsen, og kun når der kan opnåes bred enighed, bliver væsentlige nyskabelser gennemført. Der er således mange gode kræfter, der trækker på den samme hammel, og vi ser derfor på sin vis fremtiden trygt i møde. Men det forhindrer ikke, at vi prøver at forebygge, at den kommer bag på os med ubehagelige overraskelser. 